\title{
Adsorption Behavior of Gold(III) on Hydrous Lead Dioxide from Dilute Sulfuric Acid Solution
}

\author{
Katsuaki OMORI and Toshio MATSUdA \\ Department of Chemistry, Faculty of Science and Engineering, Ritsumeikan University, Kyoto 603, Japan
}

Keywords Adsorption, gold(III), hydrous lead dioxide, dilute sulfuric acid solution, atomic absorption spectrometry

Hydrous lead dioxide (HLD), freshly prepared by hydrolysis of lead tetraacetate, has been investigated to elucidate its adsorption properties and explore its potential application as an adsorbent. The adsorption behavior of various metal ions such as $\mathrm{Bi}(\mathrm{III})^{1,2}, \mathrm{Cr}$ (III), $\mathrm{Cr}(\mathrm{VI})^{3}, \mathrm{Tl}(\mathrm{I})$, and $\mathrm{Tl}(\mathrm{III})^{4,5}$ has been studied. HLD has characteristic properties associated with its strong adsorbing ability and strong oxidizing potential.

In a previous report, the adsorption behavior of $\mathrm{Au}(\mathrm{III})$ in hydrochloric acid solution was investigated. ${ }^{6}$ The hydrochloric acid concentration was low enough to prevent a decrease in HLD owing to reactions with $\mathrm{Cl}^{-}$. The adsorption increased with increasing $\mathrm{pH}$, beginning at 0 , reaching $100 \%$ at $\mathrm{pH} 2-7$, and decreasing with increasing $\mathrm{pH}$ values above 8 . These results show that the main species involved in the adsorption was an $\mathrm{Au}(\mathrm{III})$ chloride complex anion such as $\mathrm{AuCl}_{4}^{-}$.

In the present study, the adsorption behavior of $\mathrm{Au}$ (III) was studied using the sulfuric acid solution of $\mathrm{Au}(\mathrm{III})$. The results are compared with those of the adsorption behavior of $\mathrm{Au}(\mathrm{III})$ in dilute hydrochloric acid solution.

\section{Experimental}

\section{Reagents}

Sulfuric acid solution of $\mathrm{Au}(\mathrm{III})$ : the stock solution was prepared by dissolving auric hydroxide in $10 \mathrm{M}$ sulfuric acid to make $\mathrm{Au}$ (III) with a concentration of about $1.5 \times 10^{-2} \mathrm{M}$. Auric hydroxide was precipitated from a concentrated tetrachloroauric acid solution by dropwise addition of sodium hydroxide solution.

Lead tetraacetate solution: the solution was prepared and standardized as described in a previous report. ${ }^{6}$

The other reagents were of analytical-reagent grade, and the water used was purified by distilling demineralized water containing small amounts of potassium permanganate and sodium hydroxide.

\section{Apparatus}

Atomic absorption spectrometry(AAS) measurements were made with a Nippon Jarrell-Ash AA-855 flame atomic absorption spectrophotometer.

The other pieces of apparatus used were also described in a previous study. ${ }^{6}$

\section{Procedure}

HLD was prepared by hydrolyzing a given volume of tetraacetate solution, as described in a previous report. ${ }^{6}$ HLD $\left(5 \times 10^{-4} \mathrm{~mol}\right)$, a known amount of sulfuric acid solution of $\mathrm{Au}(\mathrm{III})$, and an appropriate buffer solution were added to a $200 \mathrm{ml}$ Erlenmeyer flask with a rubber stopper and the mixture was diluted to $100 \mathrm{ml}$ with distilled water. The $\mathrm{pH}$ or acidity of the suspension was

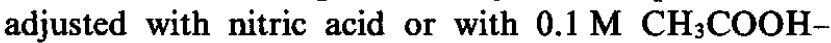
$0.1 \mathrm{M} \mathrm{CH}_{3} \mathrm{COONa}$ buffer. The suspension was shaken for $1 \mathrm{~h}$ at $30^{\circ} \mathrm{C}$. The HLD was then separated by filtration, using a membrane filter (Toyo Kagaku, Cellulose Nitrate Type, pore size $0.45 \mu \mathrm{m})$. Au(III) in the filtrate was determined by AAS, and the amount of Au(III) adsorbed was calculated from the difference in its concentration before and after adsorption.

\section{Results and Discussion}

\section{Preparation of sulfuric acid solution of $A u(I I I)$}

The solution was prepared by dissolving auric hydroxide in $10 \mathrm{M} \mathrm{H}_{2} \mathrm{SO}_{4}$ until it was saturated. The auric hydroxide was prepared as follows. Sodium hydroxide solution was added dropwise to saturated tetrachloroauric acid solution, and the resulting precipitate was washed thoroughly by adding water and then centrifuged to separate it from the water. The precipitate was then dissolved in warm $5 \mathrm{M} \mathrm{NaOH}$, again precipitated by the addition of $\mathrm{HNO}_{3}$, and washed with water as described above. The above operation was repeated four times.

The amount of $\mathrm{Cl}^{-}$in the precipitate was examined. The precipitate was dissolved in $5 \mathrm{M} \mathrm{NaOH}$, and $\mathrm{Cl}^{-}$and $\mathrm{Au}(\mathrm{III})$ in the solution were determined by spectrophotometry with mercury thiocyanate ${ }^{7}$ and AAS, respectively. It was found that the $\mathrm{Cl}^{-}$concentration 
was less than $0.6 \%$ relative to the $\mathrm{Au}(\mathrm{III})$ concentration.

\section{Adsorption behavior}

The effect of $\mathrm{pH}$ on the adsorption of $\mathrm{Au}(\mathrm{III})$ on HLD from dilute $\mathrm{H}_{2} \mathrm{SO}_{4}$ solution is shown in Fig. 1, which also shows the effect of $\mathrm{pH}$ on the adsorption of $\mathrm{Au}$ (III) from dilute $\mathrm{HCl}$ solution, for purposes of comparison. $\mathrm{Au}(\mathrm{III})$ concentration was $1 \times 10^{-5} \mathrm{M}$ and the ratio of $\mathrm{H}_{2} \mathrm{SO}_{4}$ concentration to $\mathrm{Au}(\mathrm{III})$ concentration in the solution $\left(\left[\mathrm{H}_{2} \mathrm{SO}_{4}\right] /[\mathrm{Au}(\mathrm{III})]\right)$ was 700 . The adsorption was almost $100 \%$ at $\mathrm{pH} 0-2$; at higher acid concentrations, the adsorption decreased with the increase in acid concentration.

The above result was compared with that obtained using dilute $\mathrm{HCl}$ solution. As shown in Fig. 1, the

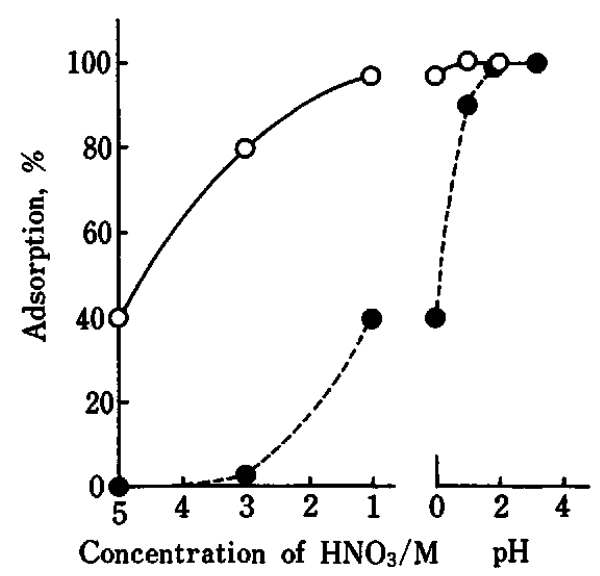

Fig. 1 Effect of $\mathrm{pH}$ and acidity on the adsorption of $\mathrm{Au}(\mathrm{III})$ on hydrous lead dioxide (HLD). HLD, $5 \times 10^{-4} \mathrm{~mol}$; [Au(III)], $1 \times 10^{-5} \mathrm{M}$, solution volume, $100 \mathrm{ml}$; shaking time, $1 \mathrm{~h}$; solutions: $\bigcirc$ dilute $\mathrm{H}_{2} \mathrm{SO}_{4}\left(\left[\mathrm{H}_{2} \mathrm{SO}_{4}\right] /[\mathrm{Au}(\mathrm{III})]=700\right)$; dilute $\mathrm{HCl}\left(\left[\mathrm{Cl}^{-}\right] /[\mathrm{Au}(\mathrm{III})]=10\right)$.

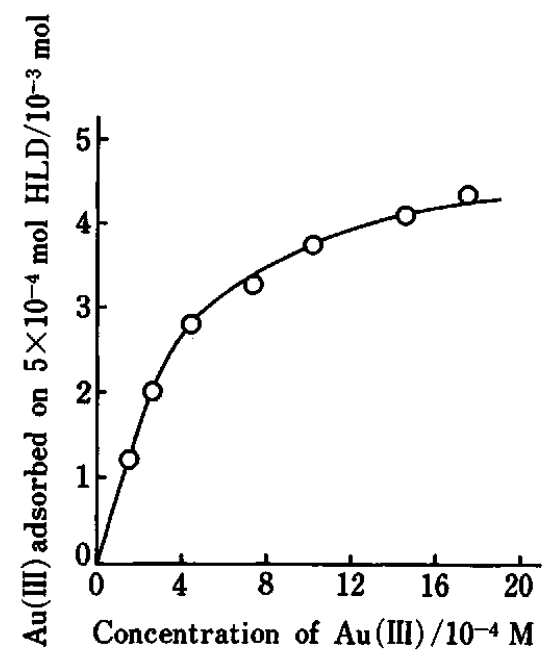

Fig. 2 Relation between concentration of $\mathrm{Au}(\mathrm{III})$ added and the amount of $\mathrm{Au}(\mathrm{III})$ adsorbed on HLD. HLD, $5 \times 10^{-4}$ $\mathrm{mol} ;\left[\mathrm{H}_{2} \mathrm{SO}_{4}\right] /[\mathrm{Au}(\mathrm{III})], 700 ;\left[\mathrm{HNO}_{3}\right], 3 \mathrm{M}$; solution volume, $100 \mathrm{ml}$; shaking time, $1 \mathrm{~h}$. adsorption was still about $80 \%$ in $3 \mathrm{M} \mathrm{HNO}_{3}$ with dilute $\mathrm{H}_{2} \mathrm{SO}_{4}$ solution. With dilute $\mathrm{HCl}$ solution, the adsorption decreased with decreasing $\mathrm{pH}$ values of 2 or below, and $\mathrm{Au}(\mathrm{III})$ was adsorbed very little in $3 \mathrm{M} \mathrm{HNO}_{3}$. The difference in the adsorption in the two cases is discussed in a later section.

No decrease in $\mathrm{Au}$ (III) concentration caused by hydrolysis was found during $1 \mathrm{~h}$ of shaking in the range of $\mathrm{pH}$ and acid concentration studied.

The relation between the concentration of $\mathrm{Au}$ (III) and the amount of $\mathrm{Au}(\mathrm{III})$ adsorbed on HLD was investigated at $3 \mathrm{M} \mathrm{HNO}_{3}$ with $5 \times 10^{-4} \mathrm{~mol}$ of HLD. The ratio of $\left[\mathrm{H}_{2} \mathrm{SO}_{4}\right]$ to $[\mathrm{Au}(\mathrm{III})]$ was 700 . The results are shown in Fig. 2, and a log-log plot of the equilibrium concentration of $\mathrm{Au}(\mathrm{III}) v s$. the amount of $\mathrm{Au}(\mathrm{III})$ adsorbed was linear.

Subsequent experiments were carried out to investigate the origin of the difference in the adsorption behavior exhibited in Fig. 1. From the $\mathrm{H}_{2} \mathrm{SO}_{4}$ stock solution of $\mathrm{Au}(\mathrm{III}), 0.4,1$ and $5 \mathrm{M} \mathrm{H}_{2} \mathrm{SO}_{4}$ solutions containing $1 \mathrm{mM} \mathrm{Au(III)}$ were prepared, and the variation of the concentration of $\mathrm{Au}(\mathrm{III})$ with time was investigated for each solution using polarography. The results are shown in Fig. 3. The concentration of $\mathrm{Au}$ (III) decreased appreciably with time at low acid concentration, and a reddish-brown precipitate of auric hydroxide formed. Figure 3 also shows for comparison the result obtained using a $0.4 \mathrm{M} \mathrm{H}_{2} \mathrm{SO}_{4}$ solution of $1 \mathrm{~m} \mathrm{M} \mathrm{AuCl} 4^{-}$, which was prepared from the $\mathrm{Au}$ (III) standard solution as mentioned in a previous report. ${ }^{6}$ With dilute $\mathrm{HCl}$ solution the concentration of $\mathrm{Au}$ (III) did not change with time. The above results indicate that the interaction between the $\mathrm{Au}$ (III) ion and $\mathrm{OH}^{-}$was stronger in dilute $\mathrm{H}_{2} \mathrm{SO}_{4}$ solution than in dilute $\mathrm{HCl}$ solution.

In addition, the variation in the spectrum of $\mathrm{Au}(\mathrm{III})$ in dilute $\mathrm{H}_{2} \mathrm{SO}_{4}$ solution was examined; the molar ratio of $\mathrm{Cl}^{-}$to $\mathrm{Au}(\mathrm{III})$ was altered by adding $\mathrm{KCl}$ solution. The concentrations of $\mathrm{Au}(\mathrm{III})$ and $\mathrm{H}_{2} \mathrm{SO}_{4}$ in the solution are

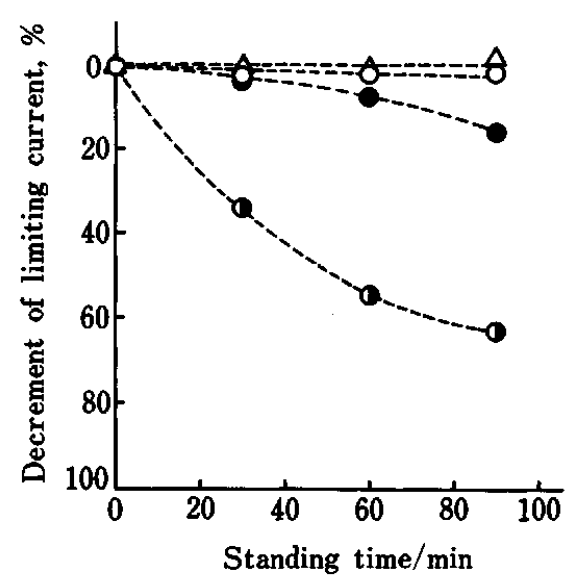

Fig. 3 Effect of concentration of $\mathrm{H}_{2} \mathrm{SO}_{4}$ on the hydrolysis of $\mathrm{Au}(\mathrm{III}) . \quad[\mathrm{Au}(\mathrm{III})]: 1 \times 10^{-3} \mathrm{M}$; temp., $25^{\circ} \mathrm{C} ;\left[\mathrm{H}_{2} \mathrm{SO}_{4}\right]: \mathrm{O}$ $0.4 \mathrm{M} ; 1 \mathrm{M} ; 5 \mathrm{M}$. $\triangle: 1 \times 10^{-3} \mathrm{M} \mathrm{AuCl}_{4}^{-}$in $0.4 \mathrm{M} \mathrm{H}_{2} \mathrm{SO}_{4}$. 


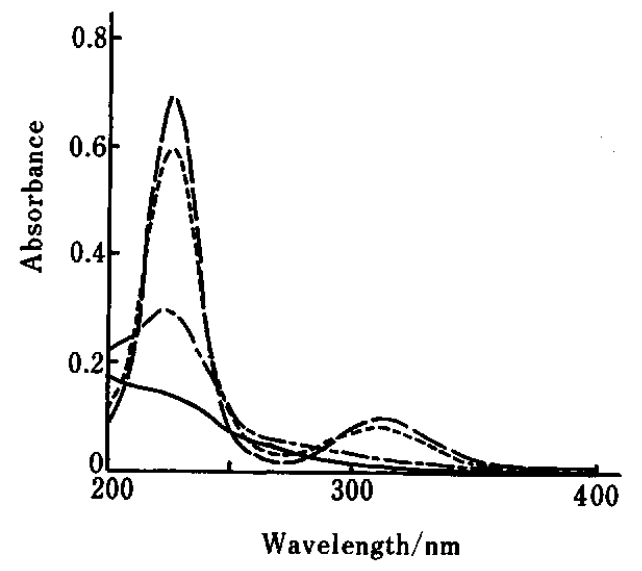

Fig. 4 Absorption spectral change of $\mathrm{Au}(\mathrm{III})$ in $\mathrm{H}_{2} \mathrm{SO}_{4}$ induced by addition of $\mathrm{Cl}^{-}$. [ $\left.\mathrm{Au}(\mathrm{III})\right], 2 \times 10^{-5} \mathrm{M} ;\left[\mathrm{H}_{2} \mathrm{SO}_{4}\right]$, $0.5 \mathrm{M} ;\left[\mathrm{Cl}^{-}\right] /[\mathrm{Au}(\mathrm{III})],-0 ;---2 ;----5 ;---10$.

$2 \times 10^{-5} \mathrm{M}$ and $0.5 \mathrm{M}$, respectivly. As shown in Fig. 4 , the spectrum was in accord with that ${ }^{8}$ of $\mathrm{AuCl}_{4}^{-}$when the molar ratio of $\mathrm{Cl}^{-}$to $\mathrm{Au}(\mathrm{III})$ was 10 (In dilute $\mathrm{HCl}$ solution the molar ratio is approximately equal to 10 .). The spectral change in Fig. 4 suggests that the replacement of ligands in a sulfate complex ${ }^{9}$ by $\mathrm{Cl}^{-}$takes place readily to give finally $\mathrm{AuCl}_{4}^{-}$. This result supports the above-mentioned results of the hydrolyzability of $\mathrm{Au}(\mathrm{III})$.

From these results we concluded as follows. In dilute $\mathrm{HCl}$ solution, neither the chloride exchange reaction of
$\mathrm{AuCl}_{4}{ }^{-}$nor the redox reaction between $\mathrm{HLD}$ and $\mathrm{AuCl}_{4}{ }^{-}$ occurred during the process of adsorption and $\mathrm{AuCl}_{4}{ }^{-}$is the main species involved in the adsorption. On the other hand, in dilute $\mathrm{H}_{2} \mathrm{SO}_{4}$ solution, hydrolysis of $\mathrm{Au}$ (III) may occur on the surface of HLD, resulting in an increase in adsorption.

The authors express their gratitude to Emeritus Professor Toyoshi Nagai of Ritsumeikan University for his suggestions and encouragement through this study.

\section{References}

1. S. Ito, T. Matsuda and T. Nagai, Bunseki Kagaku, 29, 655 (1980).

2. S. Ito, T. Matsuda and T. Nagai, Talanta, 31, 292 (1984).

3. Y. Kouji, T. Matsuda and T. Nagai, Bunseki Kagaku, 36, 356 (1987).

4. M. Miyazaki, T. Ito and T. Nagai, Bunseki Kagaku, 37, 544 (1988).

5. M. Miyazaki and T. Ito, Bunseki Kagaku, 38, 255 (1989).

6. K. Omori, T. Matsuda and T. Nagai, Bunseki Kagaku, 39, 207 (1990).

7. S. Utsumi, J. Chem. Soc. Jpn., 73, 835 (1952).

8. A. K. Gangopadhyay and A. Chakravorty, J. Chem. Phys., 35, 2206 (1961).

9. I. M. Kolthoff and P. J. Elving, "Treatise on Analytical Chemistry", Vol. 4, p. 83, Interscience Pub., New York, 1966.

(Received February 5, 1992)

(Accepted March 16, 1992) 